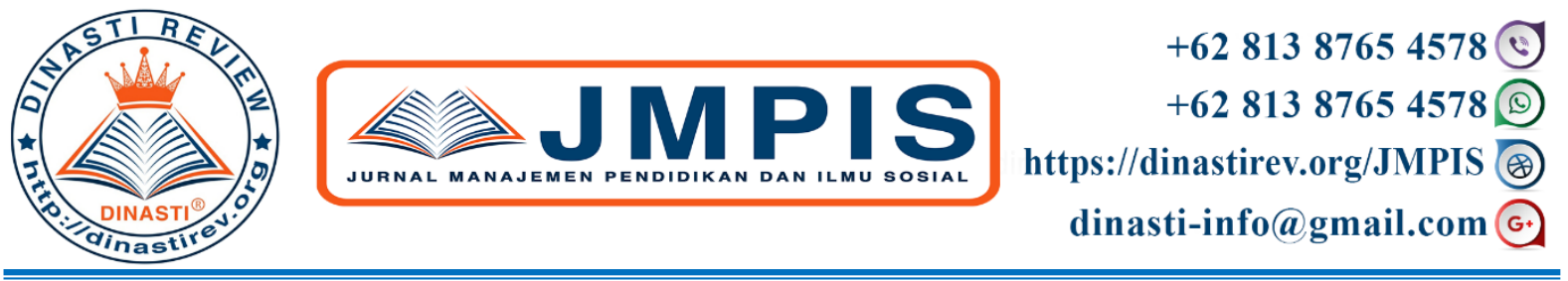

\title{
GAYA KEPEMIMPINAN PARTISIPATIF DAN KECERDASAN EMOSIONAL PENGARUHNYA TERHADAP PENGAMBILAN KEPUTUSAN DENGAN KOMUNIKASI SEBAGAI MODERASI
}

\section{Fitri Yeni}

${ }^{1)}$ Universitas Putra Indonesia YPTK, Padang, Indonesia

ARTICLE INFORMATION
Received: 26 April 2020
Revised: 6 Mei 2020
Issued: 12 Mei 2020
Corresponding Author:
Fitri Yeni
E-mail: fitri_yeni@upiyptk.ac.id

DOI:10.38035/JMPIS
Abstrak: Pengambilan keputusan merupakan salah satu faktor penentu kesuksesan perusahaan. Tidak tepatnya keputusan yang diambil akan menimbulkan masalah dan ketidak nyamanan dalam perusahaan. Tujuan penelitian ini adalah untuk melihat sejauhmana gayakepemimpinan partisipatif dan kecerdasan emosional berpengaruh terhadap pengambilan keputusan dengan komunikasi sebagai moderasi pada Bank Syariah Mandiri di Kota Padang. Populasi dalam penelitian ini meliputi seluruh karyawan Bank Syariah Mandiri di kota padang dengan jumlah 101 karyawan. Seluruh karyawan tersebut akan diteliti, sehingga penelitian ini merupakan studi populasi. Analisis data menggunakan Structural Equation Model (SEM) - Pertial Least Square (PLS). Temuan dari hasil penelitian ini bahwa terdapat pengaruh positif dan tidak signifikan antara gaya kepemimpinan partisipatif terhadap pengambilan keputusan. Kecerdasan emosional berpengaruh positif dan signifikan terhadap pengambilan keputusan. Kamunikasi sebagai variabel pemoderasi mampu memperkuat pengaruh gaya kepemimpinan partisipatif terhadap pengambilan keputusan. Komunikasi sebagai variabel pemoderasi mampu memperkuat pengaruh kecerdasan emosional terhadap pengambilan keputusan.

Kata Kunci: Gaya kepemimpinan partisipatif, kecerdasan emosional, komunikasI, pengambilan keputusan

\section{PENDAHULUAN}

Salah satu lembaga keuangan yang sangat berperan dan ikut dalam perubahan kehidupan manusia adalah perbankan. Masyarakat mendapatkan banyak hal positif dari layanan perbankan mulai dari layanan konvensional sampai ke era digital seperti saat sekarang ini.Kegiatan perbankan salah satunya adalah mengumpulkan dana dari masyarakat yang disebut juga dengan simpanan kemudian memberikannya kembali ke masyarakat dalam bentuk pembiayaan dan lainnya sehingga bisa membantu masyarakat dalam miningkatkan taraf hidupnya (Alfian dan Wulansari, 2017). Seiring dengan kemajuan teknologi saat ini 
perbankan dituntut untuk lebih berinovasi dan mengatur strategi demi kemajuan organisasi. Dalam hal ini tentu tidak lepas dari kepiawaian seorang pemimpin organisasi.

Pengambilan keputusan (decision making) merupakan hal yang sering dilakukan oleh seorang pemimpin organisasi. Biasanya pimpinan akan mengambil keputusan yang sifatnya strategis, juga semua aspek lain dari organisasi seperti system control, sumberdaya manusia, struktur dan lingkungan. Keputusan akan mempengaruhi banyak hal bisa bersifat kebaikan bahkan sebaliknya (Hamid, 2016). Cara seorang pemimpin dalam mengambil keputusan sangat mempengaruhi dalam menggerakkan bawahannya (Diana, 2013).Kemajuan dari organisasi tidak terlepas dari keputusan yang diambil oleh pimpinan. Keputusan yang diambil saat ini sangat menentukan masa depan organisasi (Putra, 2020). Munculnya masalah baik internal maupun eksternal dikarenakan kurang tepatnya pengambilan keputusan (Nasrullah, dkk, 2017). Kurang tepatnya keputusan yang diambil oleh pemimpin akan membuat anggota organisasi merasa kurang nyaman dalam bekerja sehingga menimbulkan rasa malas dan tidak termotivasi (Beck, 2011), Odoardi et al., 2019).

Kegiatan dalam melakukan penilaian dan menetapkan pilihan disebut juga sebagai pengambilan keputusan. Dalam pengambilan keputusan seorang pemimpin akan mempertimbangkan dan memikirkan serta memprediksi sehingga bisa menetapkan pilihan terhadap alternatif-alternatif yang ada. Dengan adanya perubahan situasi dan kondisi di perusahaanmaka seorang pimpinan harus mampu menghadapinya dengan menetapkan kebijakan tepat. Proses ini diharapkan bisa membantu agar administrasi dan organisasi berjalan lancar dan lebih baik lagi dari waktu ke waktu.

Pengambilan keputusan merupakan pendekatan yang dilakukan terhadap suatu masalah dengan pengumpulan data dan fakta dan memilih alternatif terbaik dan melakukan tindakan yang sesuai (Siagiaan, 2009). Keputusan yang diambil oleh seorang pemimpin biasanya dipengaruhi oleh gaya kepemimpinannya. Gaya kepemimpinan seorang pemimpin juga akan dipengaruhi oleh kepribadiannya. Kepribadian seorang pemimpin akan mempengaruhi bagaimana ia mengidentifikasi dan menganalisis masalah sehingga mengambil sebuah keputusan. Seorang pemimpin dituntut untuk lebih bijaksana dalam menghadapi masalah dan memutusan dengan tepat dan tidak memihak atas penyelesaian masalah tersebut.

Gaya (style) kepemimpinan merupakan tingkah laku yang ditampilkan oleh seorang pemimpin dalam suatu organisasi secara berkelanjutan (Ramadhani, 2020). Gaya kepemimpinan dalam organisasi salah satu diantaranya gaya kepemiminan partisipatif dimana seorang pemimpin dalam membuat keputusan dan kebijakan lebih menekankan pada tingginya dukungan tetapi sedikit pengarahan (Talalu, 2014). Kepemimpinan partisipatif merupakan pemimpin yang memberikan informasi kepada bawahannya dan percaya kepada bahawannya dalam pengambilan keputusan dalam kelompok (Akmalunnas, 2019). Dengan demikian, dalam pemecahan masalah adanya saling tukar ide antara pemimpin dengan bawahan sehingga terciptalah suatu keputusan (Prianto, 2016). Dalam hal ini pemimpin melibatkan anggotanya dalam mengambil keputusan sehingga keputusan tersebut bisa dilaksanakan dengan baik oleh semua pihak.

Selain gaya kepemimpinan partisipatif, pengambilan keputusan seorang pemimin juga dipengaruhi oleh kecerdasan emosionalnya. Menurut Lyn Daff et al. (2012), seseorang yang mampu mengenali perasaannya, memahami dan memaknai perasaannya, meraih dan 
membangkitkan perasaan, mengendalikan serta mengembangkan emosinya dikarenakan ia memiliki kecerdasan emosional. Pemimpin yang mampu mengendalikan dan mengontrol diri akan dapat menyelesaikan tanggungjawabnya dengan baik sehingga akan meningkatkan kinerja perusahaan (Widodo, Sunaryo dan khayrul, 2019), Kecerdasan emosional seorang pemimpin akan berdampak terhadap hasil keputusan yang diambil. Seorang pemimpin akan mampu menghadapi tantangan, bertanggungjawab, dalam menghadapi masalah selalu optimis dan selalu produktif dikarenakan kecerdasan emosional yang dimilikinya dimana sangat dibutuhkan dalam lingkungan kerja (Usman, 2019).

Kesuksesan dalam dunia kerja bisa dicapai bukan hanya melalui kemampuan kognitif saja tetapi juga dibutuhkan kemampuan emosional. Oleh sebab itu pimpinan diharapkan dapat membina diri dan bawahannya untuk memiliki kecerdasan emosional sehingga dapat mencapai kinerja yg maksimal (Ningrum, Halim dan Syamsuri, 2020). Kecerdasan emosional yang tinggi akan membuat seorang pemimpin menyadari bahwa perilaku dan hasil kerja mereka akan dipengaruhi oleh emosional oleh sebab itu mereka akan menilai dan mengatur emosi mereka sendiri (Putri dan widjaja, 2020). Dengan adanya kecerdasan emosional akan menjadikan pemimpin lebih tenang dan bijak dalam mengambil keputusan sehingga akan mengakibatkan pemimpin lebih fokus dan terarah dalam menentukan kebijaka-kebijakan dalam organisasinya. Hal ini tentunya akan berdampak terhadap kemajuan organisasi.

Selain gaya kepemimpinan partisipatif dan kecerdasan emosional, komunikasi juga merupakan salah satu variabel yang mampu mempengaruhi pemimpin dalam mengambil keputusan. Komunikasi adalah kegiatan penyampaian pesan secara internal dalam organisasi. Komunikasi dapat dikatakan baik dalam organisasi apabila arus komunikasi berjalan lancar tanpa adanya kendala (Sihombing, dkk, 2016). Komunikasi disebut juga dengan hubungan kontak antara manusia baik individu maupun kelompok (Habibie, Musriha dan Negoro, 2017). Komunikasi merupakan kegiatan menyampaikan makna diantara anggota-anggota suatu organisasi karena komunikasi yang baik akan berdampak terhadap kemajuan organisasi. Dalam pengambilan keputusan pemimpin juga perlu mengkominikasikan dengan bawahannya.

Salah satu lembaga perbankan yang ada di kota padang adalah bank syariah mandiri. Seperti lembaga perbankan lainnya bank syariah mandiri juga menjalankan peranannya yaitu mengumpulkan dana, melakukan pelayanan dan memberikan pembiayaankepada masyarakat. Dalam menjalankan peranannya tersebut tentunya akan dihadapkan kedalam berbagai masalah sehingga pemimpin dituntut untuk memilih alternatif-alternatif keputusan sebagai reaksi dari penyelesaian masalah tersebut. Dalam pengambilan keputusan ini tentu pimpinan akan bersinergi dengan anggotanya sehingga keputusan yang di ambil bisa dilaksanakan dengan baik dan menimbulkan kenyaman dalam organisasi.

Salah satu pengambilan keputusan yang di lakukan oleh pimpian bank syariah mandiri adalah berkaitan dengan rotasi dan mutasi. Pada saat ini kita semua sedang dihadapkan pada wabah covid-19 yang menyebabkan industri perbankan juga ikut terkena dampak. Dampak dirasakan terutama pada nasabah yang memiliki fasilitas pembiayaan yang penghasilannya harian, dimana usaha nasabah terkena efek covid-19 sehingga terganggu penghasilannya yang mengakibatkan nasabah kesulitan melakukan pembayaran kewajibannya kepada bank sehingga menyebabkan kredit macet. Kredit macet akan berdampak langsung terhadap portofolio bank. Pembiayaan macet dalam jumlah besar akan 
mengakibatkan pimpinan melakukan rotasi dan mutasi terhadap beberapa karyawan yang memang tidak memiliki beban kerja yang terlalu berat. Kebijakan tersebut tidak dengan SK tetap dimana sifatnya hanya sementara dan tidak harus diketahui oleh kantor pusat, dimana keputusan ini cukup hanya sampai di region area saja. Kebijakan ini biasanya dilakukan oleh pimpinan disaat terjadi wabah atau bencana, hal ini dilakukan oleh pimpinan dengan tujuan untuk penyelamatan bank.

Penelitian ini berfokus meneliti tentang bagaimana peranan gaya kepemimpinan partisipatif dan kecerdasan emosional seorang pemimipin dalam mengambil keputusan dengan komunikasi sebagai moderasi. Berbeda dengan penelitian sebelumnya yang dilakukan oleh Talalu (2014) yang meneliti tentang "Pengaruh Kepemimpin Partisipatif Terhadap Pengambilan Keputusan Di Desa Longalo" dan juga Saputra dan Copriady (2018) melakukan penelitian tentang "Pengaruh kecerdasan emosional dan pemanfaatan sistem informasi manajemen terhadap pengambilan keputusan" dimana penelitian-penelitian sebelumnya ini tidak menggunakan variabel moderasi maka hal ini yang menjadi research gap bagi penelitian ini.

\section{KAJIAN PUSTAKA \\ Pengambilan Keputusan}

Keputusan merupakan hasil dari penetapkan pilihan atas beberapa alternatif pilihan. Keputusan diambil dikarenakan terjadinya situasi diluar kondisi biasanya. Timbulnya perbedaan situasi di perusahaan mengharuskan pimpinan mempertimbangkan alternatifalternatif tindakan dan mengambil keputusan (Maulida, 2017). Menurut Fahmi (2014) keputusan merupakan suatu hal yang pasti yang tidak bisa diganggu gugat yang merupakan hasil dari proses pencarian berbagai macam masalah.

Pengambilan keputusan bisa dilakukan dengan kreatif dan inovatif. Tanpa adanya kreatifitas dalam pengambilan keputusan akan lebih cendrung dilakukan secara emosional. Dengan adanya kreativitas maka pemecahan masalah akan lebih mudah dan alternatifalternatif keputusan yang diambil akan bermanfaat bagi pencapaian organisasi. Adanya Inovasi memungkinkan pengambilan keputusan bisa melaksanakan keputusan dengan baik (Mu'faridah, 2017). Pengambilan keputusan merupakan tindakan pemecahan masalah dan menetapkan kebijakan agar tujuan organisasi tercapai dengan cara melakukan identifikasi terhadap permasalahan, melakukan analisis alternatif, pemilihan prioritas, menetapan keputusan dan melakukan evaluasi keputusan (Nuriah, 2012).

Yulk (2009) mengatakan bahwa ada beberapa prosedur yang bisa digunakan oleh seorang pemimpin dalam mengambil keputusan diantaranya: 1) keputusan autokratis, dimana menejer mengambil keputusan tanpa meminta saran dan pendapat bawahannya dan bawahan tidak mempunyai partisipasi langsung pada keputusan yang ditetapkan oleh menejer, 2) konsultasi, dalam hal ini menejer sebelum mengambil keputusan terlebih dahulu menejer meminta pendapat dan ide-ide dari bawahannya dan mempertimbangkan pendapat dan ide tersebut dalam pembuatan keputusan, 3) keputusan bersama, dimana pengambilan keputusan dilakukan secara bersama dengan bawahannya dengan cara menejer terlebih dahulu mengemukakan masalah kepada bawahannya dan mendiskusikanya, dalam hal ini menejer tidak terlalu dominan dalam pengambilan keputusan, 4) delegasi, tanggung jawab dan otoritas pengambilan keputusan diberikan oleh menejer kepada seseorang atau kelompok dan batas final pengambilan keputusan biasanya ditentukan oleh menejer dan biasanya jarang dilakukan persetujuan awal. 


\section{Gaya kepemimpinan partisipatif}

Menurut Winardi (2013) perilaku pemimpin yang biasanya akan mengantarkan seorang pemimpin pada kesuksesan dalam kepemimpinannya disebut dengan gaya kepemimpinan. Partisipatif adalah salah satu gaya kepemiminan yang bisa digunakan oleh seorang pemimin dalam menjalankan kegiatan organisasi. Menurut Wibowo (2014) gaya kepemimpinan partisipatif menunjukkan loyalitas dan kepercayaan dari bawahan kepada pemimpinnya yang dikarenakan pemimpin melibatkan bawahan ke dalam pertimbangan penuh, menerima saran dan pengetahuan serta keterampilan dari bawahannya sebelum mengambil keputusan. Gaya kepemimpinan partisipatif akan memberikan kesempatan kepada bawahan untuk memberikan pemikiran, gagasan dan keahliannya sehingga bawahan merasa memiliki peran dalam organisasi yang akan mengakibatkan bawahan merasa nyaman dan dibutuhkan oleh pimpinan.

Gaya kepemiminan partisipatif sangat erat kaitannya dengan pengambilan keputusan. Dessler (2013) mengatakan untuk menjadi pemimpin yang partisipatif seorang pemimpin dalam pembuatan keputusan harus melibatkan bawahannya. Setiap keputusan akan berdampak terhadap bawahan, ada baiknya jika sebelum keputusan diambil maka ditampung terlebih dahulu ide-ide kreatif dari bawahan dikarenakan setiap manusia dianugerahi pemikiran yang berbeda-beda. Menurut Sutikno (2014) gaya kepemimpinan partisipatif biasanya disebut gaya kepemimpinan gotong royong, dimana pemimpin dan para bawahannya secara bersama-sama menggotong dan bersama-sama pula meroyong aktivitas serta hasilnya. Ali, Ramdani dan Hamidsyukrie (2016) berpendapat bahwa gaya kepemimpinan partisipatif yaitu pemimpin yang memberikan peluang dan kesempatan kepada bawannya untuk ikut serta dalam proses memilih alternatif keputusan.

Talalu (2014) melakukan penelitiandi desa longalo tentang pengaruh kepemimpinan partisipatif terhadap pengambilan keputusan menyatakan bahwa terdapat pengaruh antara gaya kepemimpinan partisipatifterhadap pengambilan keputusan. Ini membuktikan bahwaterdapat hubungan antara gaya kepemimpinan partisipatif dengan pengambilan keputusan. Prianto (2016) mengatakan bahwa gaya kepemimpinan partisipatif diperlukan dalam pengambilan keputusan.

\section{Kecerdasan Emosional}

Kecerdasan emosional adalah kemampuan seseorang untuk memonitor perasaan sendiri dan orang lain, memiliki keyakinan dan keadaan diri serta menggunakan informasi yang didapat untuk mengarahkan pemikiran dan tindakan diri sendiri maupun orang lain (Sholihah et al., 2017). Kemampuan dari seseorang dalam memahami emosionalnya sendiri disebut sebagai dasar dari kecerdasan emosional (Goleman, 2009). Menurut Luthans (2008), seseorang dikatakan memiliki kecerdasan emosional apabila ia mampu untuk: (1) memahami emosional diri sendiri (2) memahami emosional orang lain, (3) memahami informasi dari orang lain. Selanjutnya Cooper dan Sawaf (2001) mengatakan bahwa kesuksesan seseorang dalam karir maupun organisasi dikarenakan ia memiliki kecerdasan emosional, termasuk kemamuan dalam mengambil keputusan, kepemimpinan, kebijakan strategis, komunikasi yang jujur, team work, membina kepercayaan, konsumen yang loyal dan memiliki kreasi serta berinovasi. 
Saputra, Copriady dan Sumardi (2018) melakukan penelitian tentang "Pengaruh kecerdasan emosional dan pemanfaatan sistem informasi manajemen terhadap pengambilan keputusan kepala sekolah dasar di uptd kecamatan tampan kota pekanbaru" menemukan hasil bahwa terdapat pengaruh secara signifikan antara kecerdasan emosional terhadap pengambilan keputusan Kepala Sekolah. Cappelletti (2005) mengemukakan bahwa dengan adanya kecerdasan emosional maka pengambil keputusan akan terhindar dari prokrastinasi yang mungkin saja terjadi pada model pengambilan keputusan rasional.

\section{Komunikasi}

Manusia sebagai makhluk sosial membutuhkan komunikasi, tanpa adanya komunikasi maka tidak akan terjadi interaksi. Komunikasi digunakan dalam menjalankan kehidupan bermasyarakat maupun dalam menjalankan kegiatan sebuah organisasi. Komunikasi merupakan proses pengiriman berita dengan tujuan untuk memberikan pemahaman antara anggota organisasi dari berbagai bidang yang berbeda-beda (Katidjan, Pawirosumarto dan Isnaryadi, 2017).Dengan adanya komunikasi hubungan sesama anggota organisasi semakin kuat. Komunikasi juga mengakibatkan saling mengenalnya anggota organisasi sehingga kegiatan organisasi bisa berjalan dengan lancar. Komunikasi yang baik juga menciptakan hubungan atasan dengan bawahan menjadi harmonis. Komunikasi juga merupakan penyampaian suatu informasi diantara beberapa orang dan juga merupakan pertukaran informasi diantara manusia dan mesin.

Dalam organisasi, komunikasi bisa terjadi antar pribadi maupun organisasi. Menurut Laswell (2014) komunikasi adalah proses memberi dan menerima informasibaik dalam organisasi maupun masyarakat luas. Pendapat lain mengenai komunikasi juga dikemukakan oleh Muhammad (2015) yaitu proses pemberian informasi serta defenisi antar individu. Wibowo (2013) mengatakan bahwa dalam organisasi komunikasi berfungsi sebagai pengendalian, sebagai motivasi, pengungkapan emosi, dan dan pemberian informasi. Komunikasi organisasi dikatakan berjalan efektif apabila setiap informasi tersampaikan dengan baik. Komunikasi bisa terjalin sesama karyawan dan juga dengan atasan maupun sebaliknya.

Berdasarkan kajian pustaka di atas maka hipotesis penelitian dapat dirumuskan sebagai berikut:

$\mathrm{H}_{1}$ : Gaya kepemimpinan partisipatif berpengaruh terhadap pengambilan keputusan.

$\mathrm{H}_{2}$ : Kecerdasan emosional berpengaruh terhadap terhadap pengambilan keputusan.

$\mathrm{H}_{3}$ : Kamunikasi sebagai variabel pemoderasi mampu memperkuat pengaruh gaya kepemimpinan partisipatif terhadap pengambilan keputusan.

$\mathrm{H}_{4}$ : Komunikasi sebagai variabel pemoderasi mampu memperkuat pengaruh kecerdasan emosional terhadap pengambilan keputusan.

\section{METODE PENELITIAN}

\section{Jenis Penelitian}

Penelitian ini menggunakan metode kuantitatif. Ada beberapa variasi dalam penelitian kuantitatif. Menurut Sugiyono (2017) penelitian kuantitatif merupakan metode penelitian yang digunakan untuk meneliti pada populasi atau sampel tertentu dengan teknik pengambilan sampel secara random dan pengumpulan data menggunakan instrumen 
penelitian, analisis data bersifat statistik dengan tujuan untuk menguji hipotesis yang telah ditetapkan.

\section{Populasi dan Sampel}

Penelitian ini menggunakan populasi yaitu meliputi seluruh karyawan Bank Syariah Mandiri di kota padang yang meliputi 3 unit kantor cabang dan 4 unit kantor kas dengan jumlah 101 karyawan. Seluruh karyawan tersebut akan diteliti, sehingga penelitian ini merupakan studi populasi.

\section{Metode Pengumpulan Data}

Data penelitian dikumpulkan yaitu melalui kuesioner. Kuesioner adalah salah satu teknik mengumpulkan data dengan cara responden mengisi pertanyaan atau pernyataan dan mengembalikannya kembali kepada peneliti (Sugiyono, 2013). Penyebarkan kuesioner dilakukan melalui google form kepada karyawan PT. Bank Syariah Mandiri kota padang yang berisikan pertanyaan mengenai variabel-variabel yang diteliti.

\section{Teknik Analisa Data}

Teknik analisis yang digunakan yaitu Structural Equation Model (SEM) - Pertial Least Square (PLS). SEM ialah metoda analisis data multivariat yang melibatkan metoda statistik secara bersamaan dan menganalisis beberapa variabel terkait dengan individu, perusahaan, peristiwa, kegiatan, situasi, dan lain sebagainya (Joseph et al, 2014).Uji yang digunakan dalam penelitian ini ialah 1 . Uji validitas berguna mengukur instrument yang digunakan valid atau tidak, 2. Uji reliabilitas ialah uji mengukur kehandalan instrument penelitian dan dapat dipercaya, 3. Uji koefisien determinasi untuk melihat sumbangsih pengaruh variabel independen terhadap dependent, 4. Uji hipotesis untuk membuktikan kebenaran dari hipotesis penelitian.

\section{HASIL DAN PEMBAHASAN}

\section{Uji Validitas}

Uji validitas berfungsi mengetahui keabsahan instrument penelitian yang digunakan. Hair et al (2014) menjelaskan bahwa terdapat dua komponen dalam menguji validitas. Komponen pertama validitas konvergen yang ditentukan oleh factor loading > 0,7 dan nilai AVE > 0,5. Hasil validitas konvergen pada penelitian ini dilihat pada nilai cross loading variabel laten, hasil cross loading menunjukan bahwa indikator masing - masing variabel memiliki korelasi yang lebih tinggi dari pada variabel laten lainnya. Maka dari itu, uji validitas pada komponen validitas konvergen seluruh variabel dinyatakan valid. Komponen kedua ialah validitas diskriminan yang ditentukan apabila akar AVE > korelasi antar konstruk. Nilai AVE pada penelitian ini disajikan pada tabel 1 sebagai berikut:

Tabel 1. Average Variance Extracted (AVE)

\begin{tabular}{lcc}
\hline \multicolumn{1}{c}{ Variable } & AVE & Akar AVE \\
\hline Gaya Kepemimpinan Partisipatif & 0.707 & 0.841 \\
\hline Kecerdasan Emosional & 0.721 & 0.849 \\
\hline Komunikasi & 0.744 & 0.863 \\
\hline
\end{tabular}




\begin{tabular}{ccc} 
Variable & AVE & Akar AVE \\
\hline Pengambilan Keputusan & 0.727 & 0.853
\end{tabular}

Berdasarkan tabel 1 di atas, menunjukkan nilai akar AVE pada tiap variabel lebih tinggi dari pada korelasi antar konstruk. Maka dari itu,dari kedua hasil komponen tersebut seluruh indikator dinyatakan valid.

\section{Uji Reabilitas}

Uji reliabilitas digunakan untuk mengukur kehandalan, konsistensi dan ketepatan instrument penelitian yang digunakan (Jogiyanto et al, 2009). Uji reliabilitas dalam PLS dapat menggunakan dua metode, yaitu composite reliability dan cronbach alpha dimana jika variabel yang diukur mempunyai nilai lebih besar dari 0,7 variabel penelitian tersebut dapat diakatakan reliabel. Hasil uji reliabilitas disajikan pada tabel 2 sebagai berikut:

Tabel 2. Hasil Uji Reabilitas

\begin{tabular}{lll}
\hline \multicolumn{1}{c}{ Construct } & Composite Reliability & Cronbach's Alpha \\
\hline Gaya KepemimpinanPartisipatif & 0.966 & 0.961 \\
\hline KecerdasanEmosional & 0.960 & 0.954 \\
\hline Komunikasi & 0.963 & 0.957 \\
\hline Pengambilankeputusan & 0.967 & 0.962
\end{tabular}

Berdasarkan tabel 2 di atas, bahwasanya nilai composite reliability dan cronbach alpha tiap variabel menunjukkan > 0,7 maka seluruh variabel dinyatakan reliabel.

\section{Uji Koefisien Determinasi (R Square)}

Uji koefisien determinasi ialah melihat kontribusi pengaruh variabel independen terhadap dependen. Hasil uji koefisien determinasi disajikan pada tabel 3:

Tabel 3. Hasil R - Square

\begin{tabular}{ll}
\hline Contruct & R-Square \\
\hline Pengambilan Keputusan & 0.869
\end{tabular}

Berdasarkan tabel 3 menunjukkan bahwa nilai R-square yaitu 0,869, diartikan bahwa variabilitas konstruk kepemimpinan partisipatif dan kecerdasanemosional berkontribusi sebesar $86,9 \%$ terhadap pengambilan keputusan, sedangkan sisanya 13,1\% dipengaruhi oleh variabel lain.

\section{Uji Hipotesis}

Pengujian hipotesis dilakukan dengan melihat nilai t-statistics pada tingkat signifikansi sebesar 95\% $(\alpha=0.05)$, dengan nilai t-tabel yaitu 1,96. Syarat untuk menolak dan menerima hipotesis merujuk pada nilai 1.96, arti kata lain, apabila nilai t-tabel lebih dari 1.96 maka hipotesis akan diterima, begitu pula sebaliknya apabila nilai t-tabel lebih kecil dari nilai 1,96 maka hipotesis penelitian ditolak. Hasil pengujian hipotesis disajikan pada tabel 4 sebagai berikut: 
Tabel 4. Hasil Uji Hipotesis

\begin{tabular}{lllll}
\hline & $\begin{array}{c}\text { Original sample } \\
(\mathbf{O})\end{array}$ & Sample Mean (M) & $\begin{array}{c}\text { Standard Deviasi } \\
(\text { STDEV) }\end{array}$ & $\begin{array}{c}\text { T Statistics } \\
(\text { O/STERR) }\end{array}$ \\
\hline $\mathrm{X} 1>\mathrm{Y}$ & 0.06 & 0.075 & 0.13 & 0.461 \\
\hline $\mathrm{X} 2>\mathrm{Y}$ & 0.538 & 0.544 & 0.118 & 4.561 \\
\hline Moderating Effect X1 & -0.313 & -0.283 & 0.128 & 2.446 \\
\hline Moderating Effect X2 & 0.382 & 0.355 & 0.13 & 2.925 \\
\hline
\end{tabular}

Berdasarkan tabel 4 di atas, maka dapat disimpulkan bahwa:

\section{Hipotesis 1 : Pengaruh gaya kepemimpinan partisipatif terhadap pengambilan keputusan}

Variabel gaya kepemimpinan partisipatif berpengaruh positif dan tidak signifikan terhadap pengambilan keputusan nilai koefisien parameter (original sample) sebesar 0.06 dan signifikan pada alpha $=0,05$ dimana nilai statistiknya $0,461<1,96$ ( $\mathrm{t}_{\text {hitung }}<\mathrm{t}_{\text {tabel }}$ ) sehingga hipotesis satu ditolak. Artinya pada perspektif responden bahwa kepemimpinan partisipatif pada Bank Syariah Mandiri Kota Padang belum terlaksana dengan baik sehingga menunjukkan pengaruh yang tidak signifikan. Secara konsep, kepemimpinan partisipatif merupakan pemimpin dimana dalam pengambilan keputusan akan berkonsultasi dengan bawahan dalam hal pekerjaan, tujuan tugas dan cara menyelesaikannya, sehingga dengan keikutsertaan bawahan dalam mengambil keputusan, karyawan merasa ikut berkontribusi untuk mengembangkan perusahaan (Akmallunas, 2019). Dalam hasil penelitian ini, pada perspektif responden bahwasanya pimpinan belum menganut kepemimpinan partisipatif sepenuhnya. Maka dari itu responden merasa bahwa konsultasi dan sharing perlu dilakukan bersama pimpinan agar dapat mengambil keputusan yang lebih baik sehingga karyawanpun merasa nyaman dalam melaksanakan keputusan itu. Hasil penelitian ini tidak sejalan dengan hipotesis yang diajukan sebelumnya. Temuan ini bertolak belakang dengan penelitian yang telah dilakukan oleh Talalu (2014) dan Prianto (2016) yang menemukan bahwa gaya kepemimpinan partisipatif memiliki pengaruh terhadap pengambilan keputusan.

\section{Hipotesis 2 : Pengaruh kecerdasan emosional terhadap pengambilan keputusan}

Variabel kecerdasan emosional berpengaruh positif dan signifikan terhadap Pengambilan keputusan (koefisien parameter 0,538) dan signifikan pada alpha $=0,05$ dengan nilai statistiknya 4,561 >1,96 ( $\left.\mathrm{t}_{\text {hitung }}>\mathrm{t}_{\text {tabel }}\right)$ sehingga hipotesis dua diterima. Ningrum, Halim dan Syamsuri (2020) berpendapat bahwa kecerdasan emosional ialah kemampuan seseorang dalam memahami dan merasakan serta menjadikan kepekaan sebagai sumber energy dalam menjalankan aktivitas. Lebih jauh lagi, Sanjaya (2019) menjelaskan bahwa kecerdasan emosional dapat menunjukkan integritas seseorang, mampu berfikir jernih dan bertindak sesuai etika. Dengan kata lain, kecerdasan emosional dapat mempengaruhi seseorang agar dapat berfikir jernih dalam pengambilan keputusan kearah yang lebih strategis. Temuan penelitian ini mendukung pendapat tersebut bahwasanya kecerdasan emosional yang dimiliki pemimpin akan mempengaruhi dan meningkatkan pengambilan keputusan dalam organisasi. Dengan memiliki kecerdasan emosional maka pemimpin dapat mempertahankan eksistensi mereka di perusahaan yang tercermin dari perilaku kerja mereka dalam mengambil keputusan-keputusan secara efektif dan tepat (Hamid, 2016). Semakin baik kecerdasan 
emosional seorang pemimpin akan berakibat semakin baik pula pengambilan keputusan yang dihasilkan pada Bank Syariah Mandiri Kota Padang. Hasil penelitian ini sejalan dengan hipotesis yang diajukan sebelumnya. Temuan ini sejalan dengan hasil penelitian Saputra, Copriady dan Sumardi (2018) dan namun tidak didukung oleh penelitian yang dilakukan oleh Mardiah, Effendi dan Siagian (2017) yang menemukan bahwa kecerdasan emosional tidak memiliki pengaruh terhadap pengambilan keputusan.

\section{Hipotesis 3 : Kamunikasi sebagai variabel pemoderasi mampu memperkuat pengaruh gaya kepemimpinan partisipatif terhadap pengambilan keputusan}

Hasil moderating effect variabel komunikasi antara kepemimpinan partisipatif terhadap pengambilan keputusan menunjukkan hasil negatif dan signifikan terhadap Pengambilan keputusan (koefisien parameter -0.313) dan signifikan pada alpha $=0,05$ dengan nilai statistiknya 2,446 >1,96 ( $\mathrm{t}_{\text {hitung }}>\mathrm{t}_{\text {tabel }}$ ) sehingga hipotesis ketiga diterima. Hal ini sejalan dengan hipotesis satu di atas, responden berpendapat bahwasanya kepemimpinan yang di anut oleh pemimpin Bank Syariah Mandiri Kota Padang belum sepenuhnya menerapkan gaya kepemimpinan partisipatif. Sehingga responden menilai bahwa komunikasi yang rendah menjadikan gaya kepemimpinan partisipatif yang dimoderasi dengan komunikasi menghasilkan nilai negatif.

\section{Hipotesis 4 : Komunikasi sebagai variabel pemoderasi mampu memperkuat pengaruh kecerdasan emosional terhadap pengambilan keputusan}

Hasil moderating effect variabel komunikasi antara kecerdasan emosional terhadap pengambilan keputusan menunjukkan hasil positif dan signifikan terhadap Pengambilan keputusan (koefisien parameter 0,382) dan signifikan pada alpha $=0,05$ dengan nilai statistiknya $2,925>1,96$ ( $\mathrm{t}_{\text {hitung }}>\mathrm{t}_{\text {tabel }}$ ) sehingga hipotesis keempat diterima. Artinya berkomunikasi dengan karyawan maupun antar pimpinan dengan meninjau aspek emosional dapat membantu dalam mengambil keputusan. Temuan penelitian ini membuktikan bahwa komunikasi mampu memperkuat hubungan antara kecerdasan emosional dengan pengambilan keputusan. Dengan demikian komunikasi yang sudah terjalin selama ini sudah baik dan perlu ditingkatkan lagi sehingga keputusan-keputusan yang diambil lebih baik dan menimbulkan suasana kondusif di dalam organisasi. Temuan ini mendukung hipotesis yang diajukan sebelumnya. Hal ini juga diperkuat dengan hasil penelitian (Artanti, Suddin dan Wardiningsih, 2019) bahwasanya kecerdasan emosional dan komunikasi memiliki hubungan yang erat dalam meningkatkan kompetensi seseorang.

\section{KESIMPULAN DAN SARAN}

Dilihat dari hasil analisis dan pembahasan dapat diambil kesimpulan bahwa terdapat pengaruh positif dan tidak signifikan gaya kepemimpinan partisipatif terhadap pengambilan keputusan.Terdapat pengaruh positif dan signifikan kecerdasan emosional terhadap pengambilan keputusan. Kamunikasi sebagai variabel pemoderasi mampu memperkuat pengaruh antara gaya kepemimpinan partisipatif dengan pengambilan keputusan. Komunikasi sebagai variabel pemoderasi mampu memperkuat pengaruh antara kecerdasan emosional dengan pengambilan keputusan.

Berdasarkan hasil penelitian variabel yang paling besar pengaruhnya dilihat dari nilai koefisien parameter (original sample). Nilai koefisien parameter yang paling besar pada penelitian ini 0.538 yaitu pengaruh kecerdasan emosional terhadap pengambilan keputusan. 
Hal tersebut mencerminkan kecerdasan emosional pada Bank Mandiri Syariah Kota Padang sudah bagus dan perlu dipertahankan dan ditingkatkan agar dalam proses menetapkan keputusan bisa dilaksanakan dengan lebih baiklagi kedepannya.

Atas dasar hasil penelitian ini maka disarankan kepada Bank Mandiri Syariah Kota Padang untuk meninjau kembali gaya kepemimpinan partisipatif dalam membuat keputusan dengan merencanakan konsultasi, sharing dan mendengarkan ide dan gagasan dari bawahan untuk dipertimbangkan dalam mengambil keputusan. Selain dari pada itu, dalam upaya menetapkan keputusan yang strategis para pimpinan perlu hendaknya menguasai kecerdasanemosional karena variabel tersebut memiliki nilai pengaruh yang lebih tinggi terhadap pengambilan keputusan. Lebih jauh lagi, membangun nuansa komunikasi tidak cukup antar karyawan akan tetapi terlebih penting antar pimpinan dan karyawan, komunikasi yang terjalin baik akan mengeratkan kesatuan hati dalam bekerja agar dapat mencapai tujuan organisasi.

\section{DAFTAR RUJUKAN}

Akmal Lunas, A. 2019. "Pengaruh Kepemimpinan Partisipatif Terhadap Kepuasan Kerja Dan Menghormati Karyawan Sebagai Variabel Mediasi Pada Perawat Di Rsud Meuraxa Kota Banda Aceh". Jurnal Ilmiah Mahasiswa Ekonomi Manajemen, 4(1), 104-115.

Alfian, R. M., \& Wulansari, P. 2017. "Pengaruh Kompetensi Dan Kecerdasan Emosional Terhadap Kinerja Pegawai Di Bank Bri Kantor Cabang Setiabudi Bandung". eProceedings of Management, 4(2).

Ali, H. M., Ramdani, A., \& Hamidsyukrie, Z. M. 2016. "Pengaruh Kepemimpinan Partisipatif Kepala Sekolah dan Iklim Kerja Organisasi terhadap Kinerja Guru SMP Negeri di Kota Mataram". Jurnal Ilmiah Profesi pendidikan, 1(2).

Artanti, E. F., Suddin, A., \& Wardiningsih, S. S. 2020. "Pengaruh Kompetensi, Komunikasi, Dan Kecerdasan Emosional Terhadap Kinerja Dosen Di Sekolah Tinggi Pariwisata Sahid Surakarta". Jurnal manajemen sumber daya manusia, 13(2).

Beck, J. S. 2011. Cognitive therapy for challenging problems: What to do when the basics don't work. Guilford Press

Cappelletti, D. 2005. "The Impact of Emotions on Probabilistic Decision Making A Research Proposal". 1-8.

Cooper, R.K., \& Sawaf, A. 2001. Kecerdasan Emosional dalam Kepemimpinan dan Organisasi $\left(4^{\text {th }}\right.$ Ed). Jakarta: Gramedia Media Pustaka.

Diana, L. 2013. "Persepsi Pegawai Terhadap Pengambilan Keputusan Oleh Pimpinan Pada Dinas Pendidikanpemuda Dan Olahraga Kabupaten Agam". 1, 101-109.

Dessler, Garry. 2013. Manajemen Sumber Daya Manusia. Alih bahasa: Eli Tanya. Penyunting Bahasa: Budi Supriyanto. Jakarta. Indeks.

Fahmi, Irham. 2014. Manajemen Strategi Teori dan Aplikasi. Bandung : Alfabeta

Fred Luhans. 2008. Organizational Behavior Eleventh Edition. New York: McGraw-Hill.

Goleman, D. 2009. Emotional intelligence: kecerdasan emosional mengapa EI lebih penting dari pada IQ. Jakarta: PT Gramedia pustaka utama.

Habibie, A. W. Musriha., Negoro, B.K. 2017. "Pengaruh Komunikasi, Kerjasama Tim Dan Pengambilan Keputusan Terhadap Kinerja Karyawan PT. Geo Given Sidoarjo". Branchmarck, 3(3).

Hair, Joseph E, Jr et al. 2014. A Primer on Partial Least Squares Structural Equation Modeeling \{PLS-SEM). California. USA. SAGE Publications, Inc.

Hamid, A. N. 2016. "Makna Kompetensi Emosi Bagi Manajer Dalam Pengambilan Keputusan". Publikasi Pendidikan, 6 (2). https://doi.org/10.26858/publikan.v6i2.1903 
Jogiyanto dan Abdillah, Willy. 2009. Konsep \& Aplikasi PLS (Partial least Square) Untuk Penelitian Empiris. Eds. Pertama. Yogyakarta: BPFE Yogyakarta.

Joseph, et al. 2014. A Primer On Partial Least Square Structural Equation Modeling (PLS$S E M)$. United States of America. Library of Congress Cataloging-in-Publication Data.

Katidjan, P. S., Pawirosumarto, S., \& Isnaryadi, A. 2017. "Pengaruh Kompensasi, Pengembangan Karir dan Komunikasi terhadap Kinerja Karyawan". MIX: Jurnal Ilmiah Manajemen, 7(3).

Lasswell, Harold D. 2014. The Structure and Action of Communication in Society. Jakarta. Gramedia Utama.

Lyn Daff, Paul de Lange, Beverley Jackling. 2012. "A Comparison of Generic Skills and Emotional Intelligence in Accounting Education". Issues in Accounting Education.27(3), pp:627-645

Mardiah, M., Effendi, R., \& Siagian, O. (n.d.). 2017. "Pengaruh Pelaksanaan Etika Profesi , Independensi , Profesionalisme dan Kecerdasan Emosional Terhadap Pengambilan Keputusan Bagi Auditor BPK RI Perwakilan Provinsi Sumatera Selatan". x, 1-16.

Maulida. 2017. "Kepemimpinan Transaksional, Pengambilan Keputusan Dan Implementasi Rencana Strategis". Jurnal Administrasi Pendidikan UPI, 24(1), 141-153.

Muhammad, Arni. 2015. Komunikasi Organisasi. Jakarta. Bumi Aksara.

Mu'faridah, E. N. N. I. S. 2017. "Peranan Gaya Kepemimpinan dan Pengambilan Keputusan Dalam Upaya Meningkatkan Prestasi Kerja di PT. Daya Maha Berkarya" (No. ztvkx). Center for Open Science.

Nasrullah, M., Rumingan, M., Nasaruddin., Niswaty, R. 2017. "Pengaruh Pengambilan Keputusan Kepala Sekolah terhadap Kinerja Guru di SMK Negeri 1 Makassar". Vol. 4, No. 2, Juli - Desember 2017, Hal 103-110 p-ISSN: 2407-1765, e-ISSN: 2541-1306

Ningrum, D. K., Halim, A., \& Syamsuri, A. R. 2020. "Pengaruh Kecerdasan Emosional, Kepuasan Kerja Dan Komitmen Organisasi Terhadap Kinerja Karyawan Pada PT. Supra Matra Abadi Aek Nabara Kabupaten Labuhanbatu". Ecobisma (Jurnal Ekonomi, Bisnis Dan Manajemen), 7(1), 76-88.

Nuriah, S. W. 2012. "Pengaruh Kewenangan Dan Pengambilan Keputusan Terhadap Efektivitas Manajerial Kepala Sekolah Menengah Atas Di Jakarta Utara". Jurnal Manajemen Pendidikan, 3(2).

Odoardi, C., Battistelli, A., Montani, F., \& Peiró, J. M. 2019. "Affective commitment, participative leadership, and employee innovation: A Multilevel investigation". Revista de Psicologia Del Trabajo y de Las Organizaciones, 35(2), 103-113. https://doi.org/10.5093/jwop2019a12

Prianto. 2016. "Pengaruh Gaya Kepemimpinan Terhadap Pengambilan Keputusan Pemerintahan Desa". Vol.05. No 01

Putra, V. M. 2020. "Persepsi Guru Terhadap Pengambilan Keputusan Kepala Sekolah di SMK Negeri Kelompok Bisnis Manajemen Kota Padang". Jurnal Bahana Manajemen Pendidikan, 2(1), 755-763.

Putri, V. L., \& Widjaja, H. 2019. "Pengaruh Kecerdasan Emosional, Penghargaan Dan Kepemimpinan Transformasional Terhadap Kepuasan Kerja Pada PT. Catur Mitra Sejati Sentosa (Mitra 10)". Jurnal Manajerial Dan Kewirausahaan, 1(1).

Ramadhani, P. U. H. 2020. "Persepsi Pegawai tentang Gaya Kepemimpinan Atasan Langsung di Dinas Sosial dan Tenaga Kerja Kota Padang". Jurnal Bahana Manajemen Pendidikan, 4(1).

Sanjaya. 2019. "Pengaruh Kecerdasan Emosional Terhadap Kinerja Pegawai Di Organisasi Perangkat Daerah". Jurnal Mahasiwa Ilmu Administrasi Publik ( JMIAP ). 1(4), 49-57.

Saputra, B., Copriady, J., \& Sumardi, S. 2018. "Pengaruh Kecerdasan Emosional Dan Pemanfaatan Sistem Informasi Manajemen Terhadap Pengambilan Keputusan Kepala 
Sekolah Dasar Di UPTD Kecamatan Tampan Kota Pekanbaru". Jurnal Manajemen Pendidikan, 5(2), 201-212.

Sholiha, M., Sunaryo, H., \& Priyono, A. A. 2017. "Pengaruh Kecerdasan Emosional Dan Kecerdasan Spiritual Terhadap Kinerja Guru Smp An-Nur Bululawang - Malang". Warta ekonomi vol. 07 no 17 februari 2017 78. 07(17), 78-92.

Siagian, Sondang P. 2009. Manajemen Sumber Daya Manusia. Jakarta: Penerbit Bumi Aksara.

Sihombing, F. P., Lie, D., Butarbutar, M., \& Thressa, S. I. 2016. "Pengaruh Komunikasi Dan Disiplin Kerja Terhadap Kinerja Karyawan Pada Café Kopi Massa Koktong Lim Ming Pematang Siantar". Sultanist: Jurnal Manajemen dan Keuangan, 4(2), 11-20.

Sugiyono. 2017. Metode Penelitian Kuantitatif, Kualitatif, dan R\&D. Bandung: Alfabeta, $\mathrm{CV}$.

Sugiyono. 2013. Metodelogi Penelitian Manajemen. Yogyakarta: Alfabeta.

Sutikno. 2014. Pemimpin dan Gaya kepemimpinan, Edisi Pertama. Lombok: Holistica

Talalu, M. A. 2014. "Pengaruh Kepemimpin Partisipatif Terhadap Pengambilan Keputusan

Di Desa Longalo Kecamatan Bulango Utara Kabupaten Bone Bolango". Publik: Jurnal Manajemen Sumber Daya Manusia, Administrasi dan Pelayanan Publik, 1(1), 31-42.

Usman, F. 2019. "Pengaruh Kecerdasan Emosi Dan Budaya Organisasi Terhadap Kinerja Melalui Kepuasan Sebagai Variabel Intervening". In Forum Ekonomi (Vol. 21, No. 2, pp. 132-142).

Wibowo, Udik Budi. 2014. Teori Kepemimpinan. Yogyakarta. BKD.

Wibowo. 2013. Perilaku Dalam Organisasi. Jakarta: Rajawali Press.

Widodo, A., Sunaryo, H., \& ABS, M. K. 2019. "Pengaruh Kecerdasan Emosional, Komitmen Organisasional, Dan Organizational Citizenship Behavior Terhadap Kinerja Karyawan PT. Bank Muamalat Cabang Malang". Jurnal Ilmiah Riset Manajemen, 8(07).

Winardi. 2013. Pimpinan dan Kepemimpinan dalam Manajemen. Jakarta. PT. Rineke Cipta. Yulk, Gary A. 2009. Kepemimpinan Dalam Organisasi. Edisi Kelima. Jakarta : Indeks 